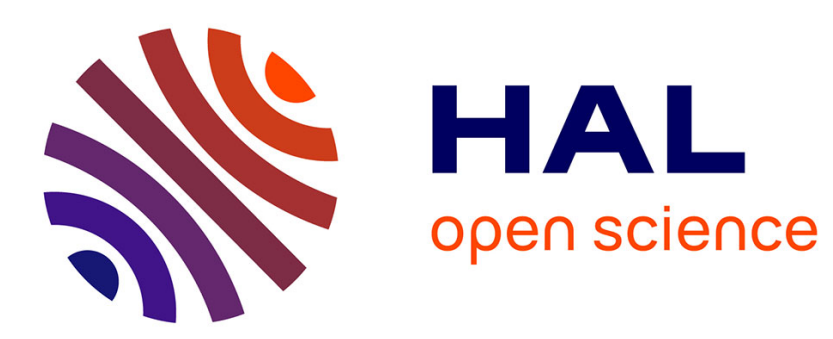

\title{
Discourse and the individual in cervical cancer screening
}

Natalie Armstrong

\section{To cite this version:}

Natalie Armstrong. Discourse and the individual in cervical cancer screening. Health:, 2007, 11 (1), pp.69-85. 10.1177/1363459307070804 . hal-00571432

\section{HAL Id: hal-00571432 \\ https://hal.science/hal-00571432}

Submitted on 1 Mar 2011

HAL is a multi-disciplinary open access archive for the deposit and dissemination of scientific research documents, whether they are published or not. The documents may come from teaching and research institutions in France or abroad, or from public or private research centers.
L'archive ouverte pluridisciplinaire HAL, est destinée au dépôt et à la diffusion de documents scientifiques de niveau recherche, publiés ou non, émanant des établissements d'enseignement et de recherche français ou étrangers, des laboratoires publics ou privés. 


\title{
Discourse and the
} Vol 11(1): 69-85

\section{individual in cervical} cancer screening

\author{
Natalie Armstrong \\ University of Warwick, $U K$
}

\begin{abstract}
A BSTRACT The official discourse on cervical screening, disseminated to women through the information material they receive when called to attend, is important for the ways in which it presents screening to women and encourages them to think about it. However, because this material is nationally produced it is designed to address a large number of women and, as a result, is necessarily general and uniform in nature. This article uses qualitative interview data to explore how individual women interpret, negotiate and make sense of this discourse in the context of their personal circumstances, experiences and characteristics; therefore producing alternative conceptualizations of, and discourses upon, cervical screening. Foucault's work on 'technologies of the self' is employed in order to suggest that these practices of individualization can be seen as the means through which a space is opened up between discourse and the individual. Within such a space the working out of individual subject positions is possible.
\end{abstract}

\section{K E Y W O R D S cervical cancer screening; discourse; Foucault; individual}

A D D R E S S Natalie Armstrong, Health Sciences Research Institute, Warwick Medical School, University of Warwick, Coventry CV4 7AL, UK. [E-mail: Natalie.Armstrong@warwick.ac.uk]

ACKNOWLEDGEMENTS The completed doctoral work on which this article draws was supported by an MRC Health Services Research Studentship. Thanks are due to Elizabeth Murphy and Nicky James for their helpful comments on the thesis as a whole.

\section{Introduction}

A national screening programme for cervical cancer has been established in the UK since 1988. The objectives are to reduce both cervical cancer incidence and mortality through a coordinated programme of regular screening for all women within a wide age range, with the aim of identifying and treating pre-cancerous abnormalities that, if left untreated, may go on 
to develop into invasive cervical cancer. When women are invited to attend for screening, they are sent a locally produced invitation letter together with a nationally produced information leaflet (Department of Health, 2002). Although the invitation letter itself may vary, the information leaflet that is required to accompany all such letters is produced and published centrally. The material contained within this leaflet can therefore be thought of as constituting the 'official discourse' on cervical screening and hence is important for the ways in which it presents screening to women and encourages them to think about it. This discourse is very general in nature as it is produced at the national level and is designed to address a large number of women. This article explores the various ways in which individual women invited to attend for cervical screening interpret, negotiate and make sense of this through considerations of their own individual circumstances, experiences and characteristics, therefore producing conceptualizations of, and discourses upon, cervical screening that are at odds with the official. These then lead to individual women working out and adopting a range of alternative subject positions instead of simply adopting the general subject position suggested to them through the official discourse. Through this process, women demonstrate an active and critical engagement with the official discourse on screening, problematize it, and raise important questions about how screening is presented and communicated to women.

\section{The official discourse on cervical cancer screening}

The NHS Cervical Screening Programme (NHSCSP) aims to reduce both the number of women who develop invasive cervical cancer, and the number of women who die from the disease.

Cervical screening in England operates in the context of the National Health Service (NHS), which is funded by general taxation and offers health care free at the point of delivery. Funding is given by the Department of Health to Primary Care Trusts (PCTs) who then commission the provision of services to interpret smear tests, report the results and provide further investigation and treatment where necessary. The programme is therefore organized and delivered locally, through PCTs, but is nationally coordinated by the National Office of the NHS Cancer Screening Programmes.

The leaflet that women receive when they are invited to participate in the screening programme, entitled Cervical screening:THE FACTS, is produced by the Department of Health in association with the NHS Cancer Screening Programmes, and with advice from the Cancer Research UK Primary Education Research Group. This leaflet, and the associated Breast screening: THE FACTS, were introduced relatively recently in order to provide clear information on the benefits and limitations of these kinds of screening and to meet the commitment in the NHS Cancer Plan (Department of Health, 2000) that all women should receive a national information leaflet on these kinds of screening by 2001. 
The material contained within this leaflet can therefore be thought of as constituting the 'official discourse' on cervical screening and hence is important for the ways in which it presents screening to women and encourages them to think about it. One of the most obvious discursive strategies used is the explicit suggestion that the material contained within represents undisputed facts. The information leaflet is, after all, entitled Cervical screening: THE FACTS, immediately suggesting that the information contained within is objective, scientific and, above all, represents some kind of 'truth'. This strong and immediate focus on the leaflet as providing 'the facts' about cervical screening suggests that any other, potentially contradictory, forms of knowledge or information that women may have acquired or developed must necessarily be incorrect. As a consequence it serves to construct the official bodies that produce the material as perhaps the only, or at least the most appropriate, people who can or should speak on such a subject. The material sent out to women in the course of their contact with the NHSCSP therefore seeks to establish itself as authoritative, objective and above all, factual. It presents women with a particular construction of cervical screening and instructs them in how to engage with cervical screening. In common with many other health promotion strategies, individuals are encouraged to behave in ways identified as sensible and responsible and to take appropriate actions to protect their health, in this case to attend for regular cervical screening.

However, it is not simply attendance for smear tests that is required; within the material, women are encouraged to engage with the screening programme in a particular way. The description of the experience of having a smear test is presented in such a way as to minimize its significance and intrusion. The test is repeatedly constructed as a simple test that will take very little time to perform and one that will usually be completely painless. Women are told that 'the test takes just a few minutes' and that the smear taker will 'gently put a small instrument ... into your vagina to hold it open'. The test itself is therefore constructed in a particular way and one that, as this article will demonstrate, does not match many individual women's experiences.

It is of course important to stress that this characterization of the official discourse is not to suggest that the medical profession as a whole, other health professionals and those involved in policy making, are unified in their views on screening. Nor do I wish to suggest that this standardized written material is the only means through which women receive information about screening. Instead, the purpose of the exercise is to characterize the official discourse and the way in which the NHS Cervical Screening Programme (NHSCSP), often through and/or with other bodies such as General Practices and Primary Care Trusts, communicates with women and presents screening to them. 


\section{Discourse and the individual}

The intention of this article is to demonstrate how women can and do demonstrate forms of resistance to the official discourse that surrounds cervical screening. This will be achieved through the analysis of qualitative interview data, which explores women's views, experiences and understandings of cervical screening, from the perspective of Foucault's later work on technologies, techniques or practices of the self as providing the means for resistance (Foucault, 1984a, 1984b, 1988). Foucault's work on governmentality (Foucault, 1991), and indeed the work of those that have developed this work (see, for example, Burchell, 1996; Dean, 1990, 1996; Rose, 1996), can be utilized as a means through which to conceptualize the official discourse on cervical screening. This work overcomes some of the problems of a previous focus on disciplinary power, as it broadens the notion of power to include a more diverse range of the means through which power can operate. There is still the possibility for repressive forms of power, but the category is widened in order to include within it an analysis at the level of individuals and their conduct in everyday life. The concept of governmentality therefore represents an extension towards more diffuse forms of social control. This formulation of power relations does not deny the possibility of a repressive form of power, but it does relegate it to one in a multiplicity of the potential effects of power (McNay, 1994). Foucault is therefore concerned with exploring the ways in which power works as a positive and enabling force through the creation of particular identities. One important way in which this new form of government operates is through discourse, and Foucault sees a 'discursive explosion' as having taken place over the last few centuries. Of particular interest to Foucault were the discourses that began to emerge around sexuality and which served to normalize heterosexuality practised within the marriage relationship. The exercise of power through discourse has the effect that the individual starts to become a self-policing subject. The concept of government is therefore extended right down to the way in which individuals come to govern themselves and become certain kinds of subjects.

In applying these ideas to the case of cervical screening, it can be argued that power is operating through the official discourse in order to construct screening in a particular way, that is as a quick, simple and painless intervention to screen for a disease that all women are potentially at risk from, and, consequently, to construct attendance for screening as something which is simply routine (Forss et al., 2001) and, perhaps more importantly, as a responsible and indeed morally correct thing to do (Bush, 2000; Howson, 1999). Empirical work of this kind is very valuable as it moves away from the focus on exploring women's perceptions and experiences of screening solely in the context of how these may influence attendance (see, for example, Bentham et al., 1995; Eaker et al., 2001; Eardley et al., 1985; Elkind et al.,1988; Neilson and Jones, 1998) and explores how women can be affected by such health promotion messages and feel obliged or constrained 
in particular ways. However, alongside such an exploration of how women can feel constrained to think and behave in particular ways, it is important to bear in mind that it does not necessarily follow that they do, or that they have no means through which to resist. To do so inevitably portrays women as little more than passive victims who have no option but to think and behave in the ways, and therefore become the kind of subjects, which the discourse encourages.

Foucault's early work is often criticized for focusing too heavily on how individuals are controlled and disciplined within society, and for paying too little attention to how power relations are viewed by the potential subjects (see, for example, Dews, 1989; McNay, 1994). It is argued that this can lead to a significant overestimation of the effectiveness of such strategies, as little attention is paid to the other discourses or knowledges that may emerge. Foucault, however, argues that his views on the nature of power have always implied the possibility of resistance, stating that, "the idea that power is a system of domination that controls everything and leaves no room for freedom cannot be attributed to me' (Foucault, 1984b: 442).

For Foucault, in order for power relations to come into existence there must be a certain degree of freedom on both sides. If there were no possibility for resistance, then there would be no power relations. Foucault's later work (Foucault,1984a,1984b,1988) develops what he calls 'technologies of the self' as a conceptualization of the ways in which individuals come to understand themselves as subjects, and therefore through which resistance is possible. Within this, a space is opened up between discourse and the individual so that a more flexible relationship can be possible, with the emphasis placed on how this is worked out (McNay, 1994). A greater element of freedom is allowed to the individual who now has the potential to interpret and negotiate rather than simply conform. Through engaging in "technologies of the self', individuals have the potential for resistance. McNay discusses this in terms of an 'ethical moment' in the process of mediation between largescale cultural patterns and individual identity. During this moment a level of 'critical self-awareness or reflexivity' (McNay, 1994:155) is achieved, and forms of identity can be questioned, thereby opening up the space for an exploration of new forms of experience. However, neither is the individual free to act in any way they wish:

I would say that if I am now interested in how the subject constitutes itself in an active fashion through practices of the self, these practices are nevertheless not something invented by the individual himself [sic]. They are models that he finds in his culture and that are proposed, suggested, imposed upon him by his culture, his society and his social group. (Foucault, 1984b: 441-2)

The relationship is not uni-directional in terms of society merely producing docile bodies, but equally neither can it be seen as a voluntarist process of self-construction. Instead, the process represents a point of contact at which techniques of domination, such as the exercise of power through 
discourse, and techniques of the self interact to produce particular subject positions (Burchell, 1996). The process is complex as particular discourses inevitably suggest more than one subject position because, while there exists a preferred form of subjectivity, its very existence implies others and the possibility for reversal. Foucault (1981) explores this through the example of sexuality, arguing that discourses surrounding this served to normalize heterosexuality practised within the marriage relationship and which produced children. Although other forms of sexuality were therefore regarded as deviant, these alternative subject positions were nonetheless inevitably created. In order to be effective, discourses need to be activated through individual agency, and this works most effectively when the subject position advocated is identified by the individual as compatible with their interests. Where this is not the case, then the necessary space for resistance is opened up. As Weedon argues, 'Where there is a space between the position of subject offered by a discourse and individual interest, a resistance to that subject position is produced' (Weedon, 1987: 112-3).

However, despite having developed such a complex theory of this process, Foucault is still criticized, but now for failing to sustain this and not going far enough in exploring how power and resistance actually work together in this relationship (see, for example, Grimshaw, 1993; Ramazanoglu, 1993; Ransom, 1993). Others, though, have been more open to how Foucault's work contributes an understanding of this relationship, and to the nature of resistance. For example, Davis and Fisher have argued that a relationship between power and resistance is a long-standing assumption within feminist scholarship, and Foucault's conceptualization of power as widely dispersed and pervasive means that resistance can be thought of in the same terms. As such, attention should be focused on how women are 'negotiating at the margins of power' (Davis and Fisher, 1993: 6), how they interact with discourse (Kielman, 1998) and their existence as critical subjects (Sawicki, 1991). I explore below the ways in which women interact with the official discourse on cervical screening and how they can demonstrate resistance to it, but first I give details on how the qualitative data that will be drawn on was collected.

\section{Methods}

The data presented here come from a qualitative interview study carried out in the East Midlands area of England with women who were all being invited to attend for screening, although not all were doing so. The universal approach to screening within a wide age range meant that a large number of women were eligible for inclusion within the study. In order to try to ensure the inclusion of as wide a range of views as possible, a quota sample was employed. This was structured according to both age and ethnic background. Age was identified as particularly important as past research has shown that older women often regard health promotion strategies as no 
longer relevant to them, but still see them as important for younger women (Savage and Clarke, 1998; White, 1995). Therefore the 20- to 64-year-old age group that was invited for screening at that time was broken down into three categories in order to represent a range of ages and stages in the life course. In terms of ethnic background, there exists a wealth of research on how particular ethnic, cultural or religious groups can hold different understandings of health and illness, and have different experiences of health care. For example, work exists on the different beliefs about, and responses to, hypertensive therapy amongst the white population and those born in the West Indies (Morgan and Watkins, 1988), how culturally defined concepts of health and illness can influence heart health-associated behaviours (Higginbottom, 2000), the health and illness understandings of African-Caribbeans, and how these may be influenced by age and gender (Curtis and Lawson, 2000), the role of culture and religion in how diabetes is managed by Kashmiri men (Naeem, 2003), and how the religious beliefs and customs of Muslim women can impact upon participation in breast and cervical cancer screening (Sutton et al., 2001; Underwood et al., 1999). A look at the population statistics for the area where the research was based showed that the three groups making up the vast majority of the population were white British, south Asian and African-Caribbean.

Women were recruited through contact with community groups within the area; in addition, personal contacts and snowball sampling were used to a limited degree. Women were given an information leaflet about the study and asked if they would be prepared to participate. The final sample of women interviewed is shown in Table 1 below.

The intention was to include four women within each cell of the table so as to give a sample of 36 women. This was deemed to be a manageable number within the context of a relatively small-scale project. There is an extra woman in the white British 50- to 64-year-old cell and this represents an individual who, although the cell was full, I interviewed as she was very keen to take part in the research. The cells for south Asian and AfricanCaribbean women of this age are both one short, and this reflects a difficulty in recruiting older women in these groups despite my best efforts to do so.

Individual in-depth interviews lasting approximately one hour were carried out with these women, either in their own homes or on the premises of the community group through which contact was made. The three interviews with south Asian women in the top age group required the use

Table 1 Quota sample

\begin{tabular}{lccc}
\hline Ethnic group & 20-34 years old & 35-49 years old & 50-64 years old \\
\hline White British & 4 & 4 & 5 \\
South Asian & 4 & 4 & 3 \\
African-Caribbean & 4 & 4 & 3 \\
\hline
\end{tabular}

Total $=35$ 
of an interpreter. All interviews were tape-recorded and transcribed with the participants' permission. Analysis of the material was approached inductively with emergent themes being identified from the interview transcripts and explored for the kinds of discourses and themes that women drew upon when talking about their views, understandings and experiences of screening. The analysis explored the women's development of alternative conceptualizations and discourses on screening that were meaningful to them.

\section{Individualization practices as techniques of resistance}

As I argued previously, the official discourse on cervical screening is important for the ways in which it presents screening to women and encourages them to think about it. It is disseminated through the material that women receive when they are invited to attend for routine smear tests and, as such, is necessarily general and uniform in nature. Women therefore encounter a very general discourse on screening, one that is designed to address a large number of women. However, it was clear from the interview data gathered that the vast majority of women do not recognize their views and experiences within this official discourse and, instead, understand and make sense of screening in ways that are meaningful to them. What I seek to do in the remainder of this article is to explore some of the ways in which individual women interpret, negotiate and make sense of screening through a consideration of their own personal circumstances, experiences and/or characteristics. Through doing so, I intend to argue that women engage in the production of alternative conceptualizations of, and discourses on, cervical screening that differ from those contained within the official discourse. As such, they are not simply accepting unquestioningly the discourse they encounter, and adopting the particular subject position suggested; instead, they are actively and critically engaging with it in particular ways in order to work out their own relationship to and with it. The key concerns of the article are therefore how women work out these relationships and the practices or techniques on which they draw in order to achieve this. Throughout, I argue that these negotiations can be framed as resistance to the official discourse through the employment of Foucauldian theory. Women's use of such practices or techniques represents the means through which a space is opened up between the official discourse and themselves as individuals.

\section{Emotional experiences}

When discussing their experiences, women frequently suggested or highlighted things about themselves that could explain their particular feelings or that meant that their experiences were likely to be different from the general presentation of cervical screening. This is most commonly the case when women regard their experiences as more difficult or troublesome than those of others and engage in a consideration of what it is about them, in 
particular, that makes this the case. Given that the presentation of cervical screening within the official material stresses the ease and simplicity of the test, it is perhaps not surprising that it is those who experience difficulties that engage in these considerations. It is as though they feel a need to negotiate a particular position for themselves in relation to this discourse and to resist the presentation of the test through the employment of their own experience.

These discussions are inevitably based upon a certain kind of knowledge, as what women can directly know about cervical screening is largely rooted in their own experiences and, to a much lesser degree, the experiences of those known to them. All of the examples explored here draw upon women's own experiences and an awareness of their bodies and emotions. This form of knowledge is necessarily specific and particularistic in nature. A woman knows what having a smear test is like through her own experiences. In this way, a great deal of the knowledge available to women is embodied and experiential (Abel and Browner, 1998; Williams and Popay, 1994). Women experience cervical screening through their bodies and, in comparison to health professionals who have access to wider technical and biomedical material, this is the main resource on which most have to draw (Howson, 1998a, 1998b).

Here, I turn first to two women who discussed the particular problems they experienced with the emotional side of cervical screening. While the majority of women discussed feeling slightly nervous and apprehensive before having a smear test, and many spoke of embarrassment during the test itself, these two women stood out as particularly extreme cases. The first of these is Debbie who talks about how much she hates going to have her smear tests and finds it very difficult to 'pluck up the courage' to go. Debbie says:

It's just something that I just hate, I think it's, you know I don't know what it is, and I know to the nurse it's nothing but I think it's just, perhaps because I'm such a private person. (Debbie, 35-49 years, white British)

It is immediately clear that having a smear test is a very difficult thing for Debbie to do, and indeed Debbie talked at length about how she took months to 'pluck up the courage' to make an appointment for her tests. On the last occasion she had been asked to make an appointment she had 'plucked up courage for about six months to actually ring up the doctor's'. On speaking to the receptionist, she was told that she needed to ensure that the appointment was between the tenth and fourteenth day of her menstrual cycle: something she had not encountered before. Debbie was unable to determine when this would be immediately and so had to say that she would call back. Having then gone away and worked it out, she had to 'pluck up the courage' to make an appointment all over again.

However, what is particularly interesting about Debbie within this extract is the way she negotiates her own position in relation to cervical screening and attempts to explain why it is that she has such problems with it. 
She appears to suggest that she finds it particularly problematic, and goes on to suggest that it may be because she is such a private person that her experiences are so difficult. In this way Debbie takes steps towards setting herself apart from other women who perhaps are not so private and do not have the same worries about exposing intimate and personal parts of their body in this way. The fact that it is in the context of a medical encounter that this exposure takes place appears to make little difference to the way Debbie feels about it. In the extract above she says that she knows 'to the nurse it's nothing', implying that she is aware that the nurse has seen this kind of thing numerous times before and that it holds no special significance for her, but this does not help Debbie. For a private person such as herself, this kind of thing will always be troublesome, and in this way Debbie negotiates her own position in relation to the discourse on cervical screening. In doing so she resists one of the central tenets of public health strategies such as screening: namely that individuals should make their bodies available to the gaze of health professionals and that this should be simply routine. This is very much the way that cervical screening is presented within the official discourse as it is discussed in terms of a simple and routine test that will take very little time. Debbie problematizes this and redraws the boundary between the public and the private by drawing on cultural ideas of certain body parts being taboo. Through this she resists the assumption that the medical gaze is permitted unlimited access to the body unproblematically.

Julia also related how she felt very anxious and nervous about going for smear tests, but discusses it in a different way to Debbie. Julia says:

I'm not a sick sort of person, in fact I can honestly say the last time I went to the doctor's was three years ago for my last screening, so I think going to the doctor's for me is quite an ordeal you know; I get quite nervous and feel sick about the fact. (Julia, 35-49, white British)

So in a similar way to Debbie, Julia is offering an aspect of herself or her circumstances to explain why her feelings about cervical screening may be different from those of others. Julia very rarely visits the doctor and so the presentation of the cervical smear test as a simple and routine test does little to allay her fear and anxiety. Going to the doctor's is not a routine occurrence for Julia; it is an unusual and unwelcome event and, as such, is something of an ordeal for her. She does not regard herself as the type of person who regularly visits the doctor; indeed, elsewhere in the interview she stressed her very good general health and her reluctance to rely on doctors to resolve minor health complaints. Julia therefore resists attempts within the official discourse to construct screening as routine and stress its role in maintaining good health, by associating it clearly with illness and literally with 'feeling sick' at the prospect of submitting herself to the medical gaze.

\section{Physical experiences}

Similar practices of resistance through individualization can be seen within women's discussions of the physical aspects of having a smear test. Again, 
whilst many made some mention of the test being uncomfortable and even painful, the two women discussed below told how their individual bodies made screening particularly difficult for them. I start with Alice, who discussed her experience of smear tests like this:

... every time uncomfortable and painful, they're just horrible ... apparently, erm, I've got a funny shape so when the instrument goes in to open your cervix up it doesn't always go properly because of the shape. (Alice, 35-49, white British)

So here Alice, in common with Debbie and Julia before her, explains how and why her experience is in some way different and unique to her. In this way she personalizes cervical screening to her own particular experiences, and indeed to her own particular body. Roberta does a very similar thing in the following extract, in which she discusses the difficulties she has experienced when having smear tests.

I've had a few; well, I have difficulties with them I must admit because they can't get at the cervix. I think it's up and back or up and to the side and the nurse has done it the last few times and has apologized profusely for not being able to do it. (Roberta, 50-64, white British)

Again, Roberta has marked her experiences out as exceptional and shows how her personal circumstances and her particular body set her apart from others. As such she goes some way towards challenging the presentation that a cervical smear test is a quick and simple test. Through these discussions, both Alice and Roberta are resisting a further assumption of public health strategies such as screening programmes. I have already suggested that such programmes are premised on the ideas that, firstly, individuals should make their bodies available for inspection by the medical gaze and that, secondly, this gaze needs to be made routine if it is to protect the health of citizens. A third premise is that the gaze requires a population of bodies that are homogenous. By surveying a large number of bodies that are 'normal' the gaze can identify the small minority that are pathological and therefore require further intervention in order to prevent illness. Through discussions of their particular bodies as different and problematic, Alice and Roberta are challenging and resisting this notion of homogenous bodies. Further, they are using a form of medical knowledge in order to achieve this as the reasons for their problematic experiences have been provided by health professionals.

The four women discussed above all therefore offer aspects about their particular circumstances to mark themselves out as somehow different, and to account for their particular experiences within the cervical screening programme. They explore their own personal and particular positions and go some way towards carving out a niche for themselves within the very general official presentation of cervical screening. These practices serve to highlight their particular positions and work out their own relationships to cervical screening whilst also resisting particular assumptions or tenets of the programme. 


\section{The changing body}

A noticeable resource on which some of the older women within my research drew when discussing cervical screening was the way in which their bodies had and were still changing, and how these changes influenced how they thought about screening and the significance that they attached to it. The majority of these discussions revolved around the menopause and the bodily changes associated with this. First, however, I explore the case of Vanessa who, at 57, was one of the oldest women I spoke to. Vanessa had gone for screening in the past but her attendance had lapsed of late due to a particularly bad experience when Vanessa felt she had been treated unsympathetically by the smear taker. What is interesting about Vanessa is the way in which her bodily changes have, in combination with her negative experience, affected her willingness to go for screening and how she feels about it. Although she had always found having a smear test embarrassing, the way in which her body was changing made the experience even more troublesome for her. Vanessa told me:

As you get older you get, like your breasts aren't as firm as they used to be, your belly starts hanging down and, you know, little bits of you start going out of shape and you think 'I don't want anybody looking at me like that, you know. I suppose if you're younger and your body's still, like not losing any of its elasticity, you kind of like, maybe you're not that bothered but as you get older I think you become a bit more conscious about how you display yourself; for me anyway that's how I feel. (Vanessa, 50-64, African-Caribbean)

The way Vanessa's body is changing with age is influencing how she feels about going for screening and having to display her body to people. The changes to her body she discusses have altered the way she views herself, and her physical attractiveness, and have made her even more reluctant to display her body in such a way. Like Debbie, Vanessa engages in a redrawing of the boundaries between the public and the private to some degree. She draws upon cultural ideas of the older body being less attractive in a society in which, it could be argued, attractive bodies are associated with youthfulness and with 'everything being where it should be'. Again, the idea that individuals should readily submit themselves to the medical gaze is problematized and resisted.

The bodily changes associated with the menopause also influenced women's thinking on cervical screening. Existing research on age and views on cervical screening (see, for example, White, 1995) has suggested that menopausal women often regard screening as of little importance to them due to a feeling that that part of their body is 'finished with'. This is supported to some degree by the views expressed in my research, as some women suggested that screening was more important for younger women who, they argued, were likely to be more sexually active and to have young children to consider. However, the menopause was also discussed in terms of being a time during which screening may be particularly important due to the perceived uncertainty and 'riskiness' of the body that the menopause 
brought about. For some women this feeling of vulnerability, combined with an awareness of how their body was changing, made screening more important to them and served to alter its meaning and significance. For Julia in particular, cervical screening had developed from simply a test to check the health of the cervix to providing a more general reassurance that the bodily changes she was experiencing were normal. Julia told me:

I feel more wary and in fact I feel more frightened than I have before because my body, since my last smear, has changed completely and I'm told it's normal for my age but I'll be glad when I've had the test and I think 'yeah, that is right', you know, there is nothing untoward happening. And I think maybe it is a very uncertain time for women of our age and maybe it is the most important period of your life to go [attend for screening] through. (Julia, 35-49, white British)

Here Julia responds to the increased uncertainty and vulnerability that she is feeling by re-appropriating the smear test to serve her own purpose. She develops it into serving a wider purpose than that within the official discourse and emphasizes its potential to reassure her that the bodily changes she is experiencing are normal. So while she is even more nervous about attending for her next smear test than she has previously been, she welcomes what she regards as its potential to put her mind at rest. In this way then she has tailored cervical screening to fit in with her particular feelings and concerns at this stage in her life and to fulfil the role that she currently requires. However, by doing so, Julia demonstrates unrealistic expectations of screening and what it can tell her about her general health status. While a normal smear test can tell Julia that the menopausal changes she has experienced have not brought about cervical abnormalities, it cannot provide more general information. Through stressing the changes to her body, Julia also goes some way towards questioning the assumption of homogenous bodies discussed previously. By drawing attention to such changes, Julia is drawing a boundary between herself and other women.

It is apparent from both Vanessa and Julia's accounts that the bodily changes they have experienced have altered the way they view cervical screening, and this highlights an important point about the fluidity of the boundaries between different subject positions in relation to cervical screening. Although women carve out a particular position for themselves in relation to the general official discourse, this is likely to shift and change as their personal situations do. Cervical screening may mean different things to a woman at different stages in her life: factors such as childbirth and menopause for example may alter its significance and meaning. Factors that were once important in defining her relationship to screening may cease to be so important and new issues may develop that take their place.

\section{Discussion}

In the course of this article I have outlined and discussed the various ways in which women work out their own positions in relation to cervical screening 
and the official discourse which surrounds it. I have focused here on three main resources upon which these women drew: emotional experiences, physical experiences, and the changing body. Throughout I argued that these practices can be conceptualized as forms of resistance to the ways in which cervical screening is presented through the official discourse and that, through such practices, women can develop alternative conceptualizations of, and discourses on, screening, which differ from and resist those contained within the official.

It must be made clear that the women within this research who advanced these alternative ways of thinking about cervical screening were not doing so to account for, or seek to justify, non-attendance. Only one woman interviewed had never had a cervical smear test taken and, of the remaining 34, 26 were regular attenders. This talk does not serve that kind of function, as even women who discussed cervical screening in very problematic terms stressed that they overcame these problems in order to attend. They were keen to stress that they had considered these problems in the context of the long-term protection of their health, thereby establishing themselves as responsible citizens (Howson, 1999; Lupton, 1995; Petersen and Lupton, 1996).

The kinds of resistance discussed in this article are important for the means through which they allow women to make sense of cervical screening in ways that are meaningful to them through the consideration and incorporation of their particular experiences, circumstances and characteristics. Women were generally reluctant to think about screening in the very general way presented in the official discourse and were keen to stress the heterogeneity of women and experience and to carve out their own position in relation to the very general. Indeed, some went as far as to use the personal to question the validity and objectivity of the medical presentation. Women were therefore keen to take back some sort of control over how screening is thought about and what meaning and significance the smear test holds for them. I would argue that resistance within this context be framed in terms of women's employment of various resources and practices in order to interpret, re-appropriate and even transform cervical screening and the cervical smear test.

This article has demonstrated that, far from being a straightforward imposition, the relationship between the official discourse on cervical screening and how it is understood and made sense of by individual women is in fact more flexible. There is clearly a space between the large-scale discourse and individual subject positions within which women draw upon a range of resources and practices that allow them to resist particular aspects of the discourse and make sense of it in the context of their own everyday lives and identities. The fact that this does not commonly lead to women resisting screening behaviourally, through a refusal to attend, should not lead us to think that this resistance is inconsequential. This range of resources and practices is important for the ways in which it influences the interpretation of health promotion messages (Davison et al., 1991) and, at times, challenges the 
objectivity of medicine by questioning the purpose of the official discourse. There are clear implications here for how screening is presented and communicated, as the accounts presented in the course of this article suggest that the full range of different women's experiences is not being represented. The resources drawn upon in these kinds of resistance then are important for their ability to suggest and impose points of resistance at the level at which discourse and the individual meet. I would therefore argue that these practices should be viewed as examples of the kinds of 'technologies of the self' Foucault envisaged when considering how resistance may be possible (Burchell, 1996; Foucault, 1984a, 1984b, 1988; McNay, 1994) through the ways in which they impose points of resistance which disrupt the flow of discourse and can lead to interpretation, negotiation and transformation.

\section{Note}

All patient names are pseudonyms.

\section{References}

Abel, E.K. and Browner, C.H. (1998). Selective compliance with biomedical authority and the uses of experiential knowledge. In M. Lock and P.A. Kaufert (Eds.), Pragmatic women and body politics, pp.310-26. Cambridge: Cambridge University Press.

Bentham, G., Hinton, J., Haynes, R., Lovett, A., and Bestwick, C. (1995). Factors affecting non-response to cervical cytology screening in Norfolk, England. Social Science and Medicine, 40(1), 131-5.

Burchell, G. (1996). Liberal government and techniques of the self. In A. Barry, T. Osborne, and N. Rose (Eds.), Foucault and political reason, pp.19-36. London: UCL Press.

Bush, J. (2000). 'It's just part of being a woman': Cervical screening, the body and femininity. Social Science \& Medicine, 50(3), 429-44.

Curtis, S. and Lawson, K. (2000). Gender, ethnicity and self-reported health: The case of African-Caribbean populations in London. Social Science and Medicine, 50(3), 365-85.

Davis, K. and Fisher, S. (1993). Power and the female subject. In S. Fisher and K. Davis (Eds.), Negotiating at the margins, pp.3-20. New Brunswick, NJ: Rutgers University Press.

Davison, C., Davey Smith, G., and Frankel, S. (1991). Lay epidemiology and the prevention paradox: The implications of coronary candidacy for health education. Sociology of Health and Illness, 13(1), 1-19.

Dean, M. (1990). Governmentality. London: Sage.

Dean, M. (1996). Foucault, government and the enfolding of authority. In A. Barry, T. Osborne, and N. Rose (Eds.), Foucault and political reason, pp.209-29. London: UCL Press.

Department of Health (2000). The NHS cancer plan. London: Department of Health.

Department of Health (in association with NHS Cancer Screening Programmes with advice and support from the Cancer Research UK Primary Research 
Education Group) (2002). Cervical screening: THE FACTS. London:

Department of Health.

Dews, P. (1989). The return of the subject in late Foucault. Radical Philosopy, 51(1), 37-41.

Eaker, S., Adami, H., and Sparen, P. (2001). Reasons women do not attend screening for cervical cancer: A population-based study in Sweden. Preventive Medicine, 32(6), 482-91.

Eardley, A., Elkind, A.K., Spencer, B., Hobbs, P., Pendleton, L.L., and Haran, D. (1985). Attendance for cervical screening - whose problem? Social Science and Medicine, 20(9), 955-62.

Elkind, A.K., Haran, D., Eardley, A., and Spencer, B. (1988). Reasons for nonattendance for computer-managed cervical screening: Pilot interviews. Social Science and Medicine, 27(6), 651-60.

Forss, A., Tishelman, C., Widmark, C., Lundgren, E., Sachs, L., and Tornberg, S. (2001). 'I got a letter...' A qualitative study of women's reasoning about attendance in a cervical cancer screening programme in urban Sweden. PsychoOncology, 10(1), 76-87.

Foucault, M. (1981). The history of sexuality volume 1: An introduction. Harmondsworth: Penguin.

Foucault, M. (1984a). The history of sexuality volume 3: The care of the self. Harmondsworth: Penguin.

Foucault, M. (1984b). The ethics of the concern for self as a practice of freedom. In S. Lotringer (Ed.), Foucault live: Collected interviews 1961-1984, pp. 432-49. New York: Semiotext(e).

Foucault, M. (1988). Technologies of the self. In L.H. Martin, H. Gutman, and P.H. Hutton (Eds.), Technologies of the self: A seminar with Michel Foucault, pp.16-49. London: Tavistock.

Foucault, M. (1991). Governmentality. In G. Burchell, C. Gordon, and P. Miller (Eds.), The Foucault effect, pp.87-104. London: Harvester.

Grimshaw, J. (1993). Practices of freedom. In C. Ramazanoglu (Ed.), Up against Foucault, pp.51-72. London: Routledge.

Higginbottom, G. (2000). Heart health-associated health beliefs and behaviours of adolescents of African and African Caribbean descent in two cities in the United Kingdom. Journal of Advanced Nursing, 32(5), 1234-42.

Howson, A. (1998a). Surveillance, knowledge and risk: The embodied experience of cervical screening. health:, 2(2), 195-215.

Howson, A. (1998b). Embodied obligation: The female body and health surveillance. In S. Nettleton and J. Watson (Eds.), The body in everyday life, pp.218-40. London: Routledge.

Howson, A. (1999). Cervical screening, compliance and moral obligation. Sociology of Health and Illness, 21(4), 401-25.

Kielman, K. (1998). Barren ground: Contesting identities of infertile women in Pemba, Tanzania. In M. Lock and P.A. Kaufert (Eds.), Pragmatic women and body politics, pp.127-63. Cambridge: Cambridge University Press.

Lupton, D. (1995). The imperative of health. London: Sage.

McNay, L. (1994). Foucault: A critical introduction. Cambridge: Polity Press.

Morgan, M. and Watkins, C.J. (1988). Managing hypertension: Beliefs and responses to medication among cultural groups. Sociology of Health and Illness, 10,561-77. 
Naeem, A.G. (2003). The role of culture and religion in the management of diabetes: A study of Kashmiri men in Leeds. The Journal of the Royal Society for the Promotion of Health, 132(2), pp.110-16.

Neilson, A. and Jones, R.K. (1998). Women's lay knowledge of cervical cancer/ cervical screening: Accounting for non-attendance at cervical screening clinics. Journal of Advanced Nursing, 28(3), 571-5.

Petersen, A. and Lupton, D. (1996). The new public health. London: Sage.

Ramazanoglu, C. (1993). Introduction. In C. Ramazanoglu (Ed.), Up against Foucault, pp.1-25. London: Routledge.

Ransom, J. (1993). Feminism, difference and discourse. In C. Ramazanoglu (Ed.), Up Against Foucault, pp.123-46. London: Routledge.

Rose, N. (1996). Governing 'advanced' liberal democracies. In A. Barry, T. Osborne, and N. Rose (Eds.), Foucault and political reason, pp.37-64. London: UCL Press.

Savage, S.A. and Clarke, V.A. (1998). Older women's illness representations of cancer: A qualitative study. Health Education Research, 13(4), 529-44.

Sawicki, J. (1991). Disciplining Foucault. New York: Routledge.

Sutton, G.C., Storer, A., and Rowe, K. (2001). Cancer screening coverage of south Asian women in Wakefield. Journal of Medical Screening, 8(4), 183-6.

Underwood, S.M, Shaikha, L., and Bakr, D. (1999). Veiled yet vulnerable: Breast cancer screening and the Muslim way of life. Cancer Practice, 7(6), 285-90.

Weedon, C. (1987). Feminist practice and poststructuralist theory. Oxford: Blackwell.

White, G.E. (1995). Older women's attitudes to cervical screening and cervical cancer: A New Zealand experience. Journal of Advanced Nursing, 21, 659-66.

Williams, G. and Popay, J. (1994). Lay knowledge and the privilege of experience. In J. Gabe, D. Kelleher, and G. Williams (Eds.), Challenging medicine. London: Routledge.

\section{Author biography}

NATALIE ARMSTRONG is a sociologist with research interests in the area of lay perceptions and experiences of health, illness and health care. She is currently a Post-Doctoral Research Fellow in the Health Sciences Research Institute at the University of Warwick. 